Article

\title{
Within-Mat Variability in Anatoxin-a and Homoanatoxin-a Production among Benthic Phormidium (Cyanobacteria) Strains
}

\author{
Susanna A. Wood ${ }^{1,2, *}$, Francine M. J. Smith ${ }^{3}$, Mark W. Heath ${ }^{4}$, Thomas Palfroy ${ }^{1}$, Sally Gaw ${ }^{3}$, \\ Roger G. Young ${ }^{1}$ and Ken G. Ryan ${ }^{4}$
}

1 Cawthron Institute, Private Bag 2, Nelson 7042, New Zealand; E-Mails: thomas.palfroy@cawthron.org.nz (T.P.); roger.young@cawthron.org.nz (R.G.Y.)

2 Department of Biological Sciences, University of Waikato, Private Bag 3105, Hamilton 3240, New Zealand

3 Department of Chemistry, University of Canterbury, Private Bag 4800, Christchurch 8140, New Zealand; E-Mails: Francine.Smith@canterbury.ac.nz (F.M.J.S.); sally.gaw@canterbury.ac.nz (S.G.)

4 School of Biological Sciences, Victoria University of Wellington, PO Box 600, Wellington 6140, New Zealand; E-Mails: Mark.Heath@vuw.ac.nz (M.W.H.); Ken.Ryan@vuw.ac.nz (K.G.R.)

* Author to whom correspondence should be addressed; E-Mail: susie.wood@cawthron.org.nz; Tel.: +64-03-548-2319; Fax: +64-03-546-9464.

Received: 21 September 2012; in revised form: 14 October 2012 / Accepted: 16 October 2012 / Published: 19 October 2012

Abstract: Benthic Phormidium mats can contain high concentrations of the neurotoxins anatoxin-a and homoanatoxin-a. However, little is known about the co-occurrence of anatoxin-producing and non-anatoxin-producing strains within mats. There is also no data on variation in anatoxin content among toxic genotypes isolated from the same mat. In this study, 30 Phormidium strains were isolated from $1 \mathrm{~cm}^{2}$ sections of Phormidium-dominated mats collected from three different sites. Strains were grown to stationary phase and their anatoxin-a, homoanatoxin-a, dihydroanatoxin-a and dihydrohomoanatoxin-a concentrations determined using liquid chromatography-mass spectrometry. Each strain was characterized using morphological and molecular (16S rRNA gene sequences) techniques. Eighteen strains produced anatoxin-a, dihydroanatoxin-a or homoanatoxin-a. Strains isolated from each mat either all produced toxins, or were a mixture of anatoxin and non-anatoxin-producing genotypes. Based on morphology these genotypes could not be separated. The $16 \mathrm{~S}$ rRNA gene sequence comparisons showed a difference of at least 17 nucleotides among anatoxin and non-anatoxin-producing strains 
and these formed two separate sub-clades during phylogenetic analysis. The total anatoxin concentration among toxic strains varied from 2.21 to $211.88 \mathrm{mg} \mathrm{kg}^{-1}$ (freeze dried weight), representing a 100 fold variation in toxin content. These data indicate that both the relative abundance of anatoxin and non-anatoxin-producing genotypes, and variations in anatoxin producing capability, can influence the overall toxin concentration of benthic Phormidium mat samples.

Keywords: $16 \mathrm{~S}$ rRNA gene sequence; anaF gene; anatoxin-a; benthic mats; cyanobacteria; homoanatoxin-a; Phormidium

\section{Introduction}

Phormidium is a cyanobacterium that can form expansive benthic mats on the substrata of lakes and rivers [1-3]. Benthic proliferations dominated by Phormidium are of concern because some strains produce the potent neurotoxic compounds anatoxin-a, dihydroanatoxin-a, homoanatoxin-a, and dihydrohomoanatoxin-a, hereafter collectively referred to as anatoxins [1,2,4]. Anatoxins are powerful neuromuscular blocking agents that act through the nicotinic acetylcholine receptor. They bind to acetylcholine receptors triggering muscle contraction or other neural signal responses. They cannot be broken down by acetylcholine esterase and cause over-stimulation. When ingested, these toxins can cause death via asphyxia from respiratory paralysis [5]. Consumption of anatoxin-containing Phormidium mats has resulted in numerous dog poisonings and fatalities worldwide [1,4,6,7].

Studies of benthic Phormidium mats in rivers across New Zealand have shown a wide variability in anatoxin concentrations $[2,4,8,9]$. Samples taken from individual sites $\left(100 \mathrm{~m}^{2}\right.$ in area) on the same day can also show a wide divergence in anatoxin content. Both anatoxin and non-anatoxin containing samples were identified and these were sometimes spaced less than $1 \mathrm{~m}$ apart [10]. Studies have also noted large differences in toxin concentrations from week to week, and within rivers on the same day [8-10].

Cyanobacterial toxin dynamics have been examined in planktonic bloom forming cyanobacteria for many decades with similar extreme variability in toxin concentrations recorded. This variability has been observed spatially and temporally in both long-term and fine scale investigations [11,12]. Within toxic planktonic blooms of anatoxin-a-producing Aphanizomenon issatschenkoi [13], saxitoxin-producing Anabaena [14], and microcystin-producing Microcystis [15,16], or Planktothrix [17], it has now been demonstrated that this variability is largely due to the co-occurrence of toxic and nontoxic genotypes. Differences in toxin content can be explained by the relative dominance of toxin-producing or non-producing strains. Culture based studies of strains isolated from blooms have also shown that toxic genotypes vary in the amounts of toxin and specific congeners produced $[14,18]$. Despite an increasing number of reports of toxic benthic cyanobacteria [19-23] there is only very limited information available on the co-occurrence of toxic and non-toxic strains $[2,10,24]$. There is no information on variation in anatoxin content among toxic strains isolated from the same benthic mat.

In this study we investigated the toxin producing abilities of 30 Phormidium strains isolated from four anatoxin-containing mats collected from three different sites. The anatoxin production potential of 
each strain was assessed using a PCR targeting the anaF gene. Strains were grown to stationary phase and their anatoxin content determined using liquid chromatography-mass spectrometry (LC-MS). Each strain was characterized using morphological and molecular (16S rRNA gene sequences) techniques.

\section{Results}

A total of 30 Phormidium strains were established from single filaments. Ten strains (CYN103-CYN112) were isolated from the Waimakariri River mat, four (CYN113, CYN115-117) and eight strains (CYN126-133) were isolated from mat 1 and mat 2 from Hutt River, Site 1 respectively, and eight strains (CYN118-125) were isolated from a mat collected at Hutt River, Site 2.

Anatoxin-a and dihydroanatoxin-a were detected in 18 of the 30 samples. One of these strains (CYN112), isolated from the Waimakariri River, also produced homoanatoxin-a (Table 1). All of the strains isolated from mat 1 from the Hutt River, Site 1, produced anatoxins. In contrast not all of the isolates from the other mats produced anatoxins; nine out of ten isolated from the Waimakariri River, one out of eight from the Hutt River, Site 2, and six out of eight from mat 2 from the Hutt River, Site 1 did not contain anatoxins (Table 1).

Among the anatoxin producing strains isolated, the concentration of anatoxins produced varied and there was no relationship between the concentration produced and the original source. For example, total anatoxins produced by the isolates from the Waimakariri River varied from 10.06 to $211.83 \mathrm{mg} \mathrm{kg}^{-1}$ and from 4.75 to $115.42 \mathrm{mg} \mathrm{kg}^{-1}$ dry weight for isolates from mat 1 , Hutt River, Site 1. Dihydroanatoxin-a concentrations were always higher than anatoxin-a (Table 1).

All strains that were found to produce anatoxins via LC-MS also tested positive by PCR for a segment of the anaF gene (Table 1). Gene segments (404 bp) from strains CYN103-107 and 109-112 were sequenced and were identical. Using Megablast, these segments shared 99\% sequence homogeneity with an anaF gene segment from strain CYN53 (JX088093), a P. autumnale strain isolated from the Rangitaiki River (North Island, New Zealand; [2]). The next closest sequence similarities were 94\% with Oscillatoria PCC 6506 (FJ477836), and 91\% with Anabaena sp. (JF803645) and A. flos-aquae (AY210784).

Partial 16S rRNA gene sequences (1340 bp) were obtained for all strains. The strains which tested positive for anatoxins (CYN103-107, 109-113, 115-118, 126-128 and 131-133) were identical over this region (Figure 1). These strains were also identical to CYN53 (JX088083). These segments had a 99\% sequence homology with Tychonema sp. K27 (GQ324965), T. bourrellyi CCAP (AB045897) and T. tenue SAG 4.82 (GQ324973). The sequences from all other strains isolated in this study, except CYN108, were identical, and were 17 nucleotides different from the anatoxin positive strains. When submitted to Megablast the closest matches (99\%) for these strains were: Phormidium sp. KU003 (AB094351), Microcoleus vaginatus SEV1-KK3, CJI-U2-KK1, PCC 9802 (EF654076, EF654078, AF284803), P. autumnale SAG 35.90, Ant-Ph68, Arct-Ph5 16S, SAG 78.79 (EF654081, DQ493874, DQ493873, EF654084), Tychonema sp. K27 (GQ324965), T. bourrellyi CCAP (AB045897) and T. tenue SAG 4.82 (GQ324973). Strain CYN108 differed from the other anatoxin negative strains by four nucleotides and an insertion of 10 nucleotides. Megablast analysis returned the same results as obtained for the other anatoxin negative strains. 
Table 1. Results of the anaF PCR and liquid chromatography-mass spectrometry (LC-MS) of 30 strains of Phormidium isolated from the Waimakariri (WR) and Hutt (HR) rivers. $-1-1=$ Site 1 , mat $1,-2=$ Site 2, $-1-2=$ Site 1 , mat 2, ND = Not detected, ATX = anatoxin-a, dhATX $=$ dihydroanatoxin, HTX $=$ homoanatoxin-a, dhHTX = dihydrohomoanatoxin. Concentrations of dhATX, HTX and dhHTX were calculated using the anatoxin-a calibration curve.

\begin{tabular}{|c|c|c|c|c|c|c|c|}
\hline \multirow{2}{*}{ Strain } & \multirow{2}{*}{ Location } & \multirow{2}{*}{$\begin{array}{l}\text { anaF } \\
\text { PCR }\end{array}$} & \multicolumn{5}{|c|}{ LC-MS data $\left(\mathrm{mg} \mathrm{kg}^{-1}\right)$} \\
\hline & & & ATX & $\operatorname{dhATX}$ & HTX & dhHTX & TOTAL \\
\hline CYN103 & WR & + & 5.92 & 205.92 & ND & ND & 211.83 \\
\hline CYN104 & WR & + & 5.79 & 156.07 & ND & ND & 161.86 \\
\hline CYN105 & WR & + & 0.28 & 40.80 & ND & ND & 41.08 \\
\hline CYN106 & WR & + & 0.47 & 56.39 & ND & ND & 56.86 \\
\hline CYN107 & WR & + & 0.93 & 9.13 & ND & ND & 10.06 \\
\hline CYN108 & WR & - & ND & ND & ND & ND & ND \\
\hline CYN109 & WR & + & 3.25 & 128.38 & ND & ND & 131.63 \\
\hline CYN110 & WR & + & 6.40 & 171.80 & ND & ND & 178.20 \\
\hline CYN111 & WR & + & 1.08 & 71.90 & ND & ND & 72.98 \\
\hline CYN112 & WR & + & 2.38 & 165.75 & 1.00 & ND & 169.13 \\
\hline CYN113 & HR-1-1 & + & 0.04 & 66.91 & ND & ND & 66.95 \\
\hline CYN115 & HR-1-1 & + & 0.25 & 28.57 & ND & ND & 28.83 \\
\hline CYN116 & HR-1-1 & + & 0.04 & 31.29 & ND & ND & 31.33 \\
\hline CYN117 & HR-1-1 & + & 0.12 & 152.16 & ND & ND & 152.28 \\
\hline CYN118 & HR-2 & + & 0.02 & 2.19 & ND & ND & 2.21 \\
\hline CYN119 & HR-2 & - & ND & ND & ND & ND & ND \\
\hline CYN120 & HR-2 & - & ND & ND & ND & ND & ND \\
\hline CYN121 & HR-2 & - & ND & ND & ND & ND & ND \\
\hline CYN122 & HR-2 & - & ND & ND & ND & ND & ND \\
\hline CYN123 & HR-2 & - & ND & ND & ND & ND & ND \\
\hline CYN124 & HR-2 & - & ND & ND & ND & ND & ND \\
\hline CYN125 & HR-2 & - & ND & ND & ND & ND & ND \\
\hline CYN126 & HR-1-2 & + & 0.19 & 115.23 & ND & ND & 115.42 \\
\hline CYN127 & HR-1-2 & + & 0.63 & 79.92 & ND & ND & 80.55 \\
\hline CYN128 & HR-1-2 & + & 0.12 & 32.58 & ND & ND & 32.70 \\
\hline CYN129 & HR-1-2 & - & ND & ND & ND & ND & ND \\
\hline CYN130 & HR-1-2 & - & ND & ND & ND & ND & ND \\
\hline CYN131 & HR-1-2 & + & ND & 4.75 & ND & ND & 4.75 \\
\hline CYN132 & HR-1-2 & + & 0.25 & 74.32 & ND & ND & 74.58 \\
\hline CYN133 & HR-1-2 & + & 0.06 & 73.56 & ND & ND & 73.62 \\
\hline
\end{tabular}

The 16S rRNA gene sequences were used to construct a phylogenetic tree. The anatoxin and non-anatoxin producing strains isolated in this study clustered in a single clade with $100 \%$ bootstrap support (Figure 1). The anatoxin-producing strains clustered most closely with Tychonema species, whilst the non-toxic strains (CYN108, 119-125, 129, 130) formed their own sub-clade (Figure 1). 
Figure 1. Phylogenetic tree based on $16 \mathrm{~S}$ rRNA gene sequences (1340 bp). The tree was constructed using the neighbour-joining method. Bootstrap values $>50 \%$ are noted at the nodes. Scale bar $=0.02$ substitutions per site. Ar = Arthrospira, Lep $=$ Leptolyngbya, Lyn $=$ Lyngbya, $M=$ Microcoleus, Osc $=$ Oscillatoria, $P=$ Phormidium, $T=$ Tychonema, $W=$ Wilmottia ${ }^{*}$ anatoxin-producing strains isolated in this study.

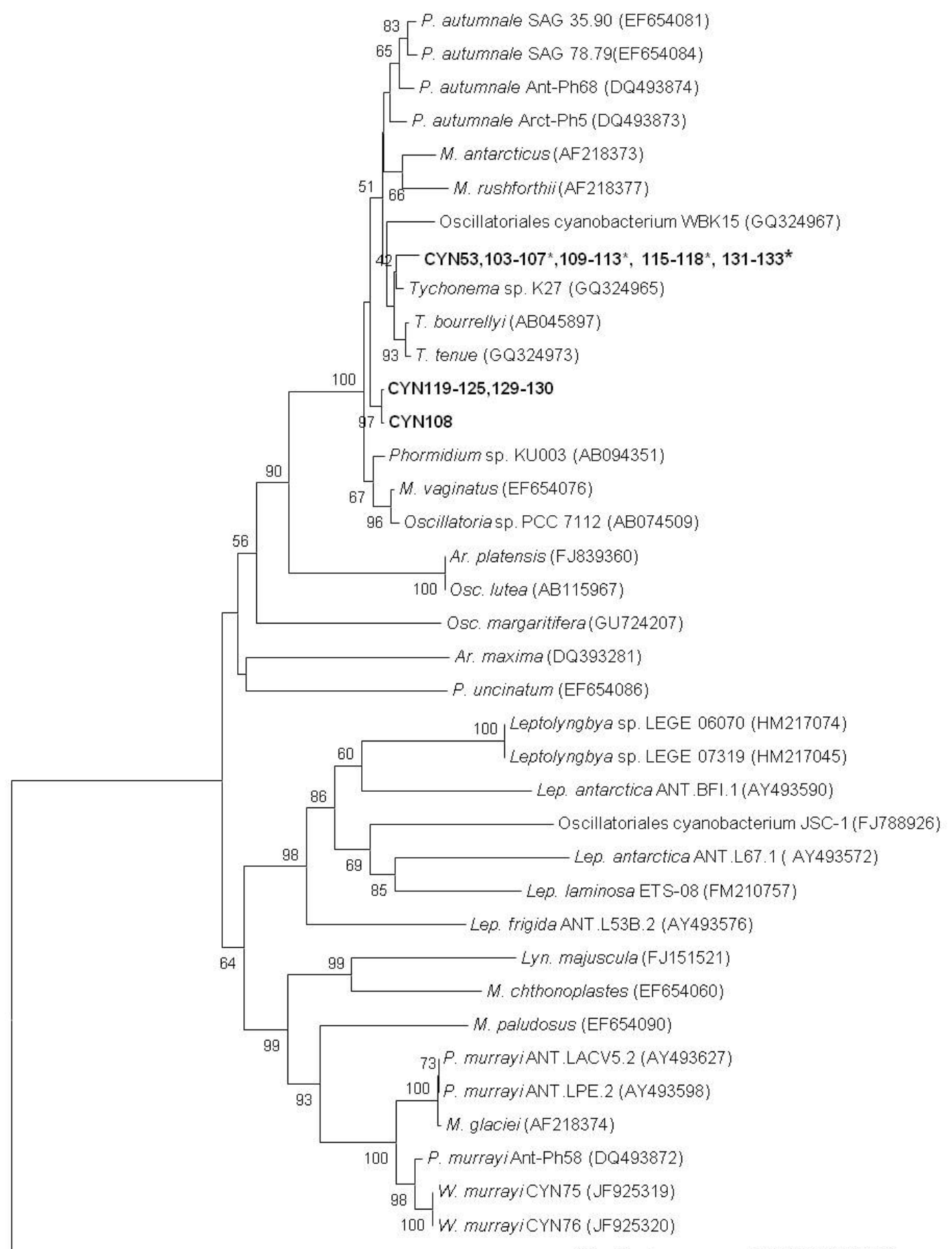

Stenotrophomonas sp. MG08 (EU048274)

All strains shared a similar morphology although there was considerable heterogeneity among cell lengths and widths. Filaments consisted of a single trichome within a firm colourless sheath. 
Trichomes were light to dark brown, motile, gradually attenuated towards apical cells, commonly forming hormogonia and not constricted at cross-walls. Cells were generally shorter than wide with some cells having densely arranged granules at cross-walls. Apical cells were rounded and occasionally capitate or calyptrate when mature. Cell dimensions among anatoxin producing strains (CYN103-107, 109-113, 115-118, 126-128 and 131-133) were 5.8-12.5 $\mu \mathrm{m}$ wide by 1.2-7.8 $\mu \mathrm{m}$ long. Among the non-anatoxin-producing strains (CYN108, 119-125, 129-130) the cell dimensions were $6.4-10.6 \mu \mathrm{m}$ wide by $2.4-4.8 \mu \mathrm{m}$ long.

\section{Discussion}

The results of this study demonstrate, for the first time, the coexistence of anatoxin- and non-anatoxin-producing Phormidium strains within small $\left(1 \mathrm{~cm}^{2}\right)$ regions of benthic mats. This co-occurrence of anatoxin and non-anatoxin-producing genotypes within benthic mats has been postulated previously, but not proved conclusively. Heath et al., [2] showed evidence for their co-occurrence by isolating seven strains of $P$. autumnale from mats that tested positive for anatoxins using LC-MS. Five of the seven strains did not produce anatoxins. Similarly, anatoxin- and non-anatoxin-producing strains of Phormidium were isolated from floating scum samples from one site on the River Tarn, France; however these strains were isolated from samples collected on different dates [24]. Despite the notably different habitats and species involved, the data from this study concurs with planktonic cyanobacteria studies where the co-occurrence of toxic and non-toxic genotypes is now well documented [13-17]. Molecular studies on natural populations of planktonic cyanobacteria have shown that the proportion of toxic and non-toxic genotypes varies as blooms progress. In many instances, these shifts in genotype composition correlate with changes in toxin concentration [25]. Although PCR assays targeting a range of genes involved in the biosynthesis of anatoxin have been developed [26], the use of quantitative PCR (QPCR) to assess changes in genotype abundance has not yet been applied to the study of benthic Phormidium. To determine if there is a relationship between the relative abundances of anatoxin and non-anatoxin-producing benthic Phormidium and anatoxin concentrations, QPCR assays targeting genes involved in anatoxin biosynthesis need to be used to study environmental sample sets.

The total anatoxins concentration of the strains isolated in this study varied from 2.21 to $211.83 \mathrm{mg} \mathrm{kg}^{-1}$ (freeze dried weight). This represents a 100 fold variation in toxin content among toxic strains. Thus in addition to the relative abundance of anatoxin and non-anatoxin-producing genotypes, variations in toxin producing capability among toxic genotypes can influence the overall toxin concentration of a benthic mat sample. The differences in anatoxin production among strains are not apparent from the presence or absence of anaF or other anatoxin biosynthetic genes. These data highlight the utility of isolating strains and using chemical analysis to increase knowledge on variations in toxin production. Anatoxin concentrations from this study (maximum $211.83 \mathrm{mg} \mathrm{kg}^{-1}$ ), were markedly lower than those measured for P. autumnale strain CYN53 (Rangitaiki River, North Island, New Zealand; [2]), which consistently produces approximately $1000 \mathrm{mg} \mathrm{kg}^{-1}$ of anatoxins [2]. This finding demonstrates that the difference between the most and least toxic strains is even greater than measured in this study. Long-term culturing of cyanobacteria can result in changes in toxin production [27]. In this study, all strains were isolated at the same time and maintained under identical 
culture conditions and therefore the differences in the quantitative amounts of anatoxins are likely to represent significant differences between strains.

A further important consideration is the relative abundances of the different anatoxin congeners and the effect of this on toxicity. Anatoxin-a and homoanatoxin-a have a mouse $\mathrm{LD}_{50}$ (lethal dose resulting in 50 percent deaths) of $200-250 \mu \mathrm{g} \mathrm{kg}^{-1}$ body weight [28,29]. Dihydroanatoxin-a has an $\mathrm{LD}_{50}$ of $2 \mathrm{mg} \mathrm{kg}^{-1}$ [30]. Among the strains in this study that contained both anatoxin-a and dihydroanatoxin-a, there was between 10 to 1600 times more dihydroanatoxin-a produced (Table 1). In contrast CYN53 produces predominately anatoxin-a [2], thus as well as producing high levels of anatoxin-a it is also producing the congener variant with the highest toxicity.

All of the strains isolated in this study fell into a single clade supported with $100 \%$ bootstrap support within the well-defined 16S rRNA gene sequence $P$. autumnale clade (Figure 1). The $P$. autumnale clade has recently been confirmed by morphological and ultrastructure data [31,32]. In the current study all of the strains shared close homology (>99\%) with species of Microcoleus and Tychonema. This observation has previously been observed for 16S rRNA sequences of $P$. autumnale strains $[2,31,32]$. Previous studies on planktonic cyanobacteria have shown that there is no, or very limited, difference in $16 \mathrm{~S}$ rRNA gene sequences between toxic and non-toxic strains [33,34]. In contrast, in this study the anatoxin and non-anatoxin-producing strains clearly fell into two separate sub-clades. Based on analysis of a 1340 base pair region of the 16S rRNA gene sequence, there was at least a 17 nucleotide differences between the genotypes. Cadel-Six [24] studied benthic cyanobacteria using a different phylogenetic marker and also observed similar results. They showed that the internal transcribed spacer regions (ITS), ITS1 and ITS2, and the 5.8S regions of rRNA operon could provide sufficient resolution to demonstrate that each neurotoxic phenotype corresponded to a distinct genotype. Based on the observed differences in the 16S rRNA gene sequences it may be possible to design a PCR-based assay to separate these genotypes. However, for distinguishing toxic and non-toxic genotypes, PCR-based assays targeting genes involved in anatoxin biosynthesis [26] would be more conclusive in identifying anatoxin potential than using an assay based on 16S rRNA gene sequences.

It is well known from research on planktonic cyanobacteria that morphology alone cannot be used to distinguish toxic and non-toxic genotypes [35,36]. A similar result has been shown for some benthic species [2] and despite variability in the 16S rRNA gene sequence phylogeny, difference in morphology could not be used to separate anatoxin and non-anatoxin-producing genotypes. This finding is consistent with Comte et al., [31] who were unable to separate $P$. autumnale strains Arct-Ph5 and Ant-Ph68 based on morphological characters, but identified them as two subspecies by genetic analysis (16S rRNA gene sequences). The general morphology of all strains in this study was similar and there was considerable variability in cell dimension within both toxic and non-toxic strains. Phormidium autumnale displays considerable plasticity, with strains varying from 1.6 to $13 \mu \mathrm{m}$ wide by 1 to $13 \mu \mathrm{m}$ long [37]. 


\section{Methods}

\subsection{Sample Sites and Collection}

Samples were collected from three sites during benthic proliferation events; Waimakariri River

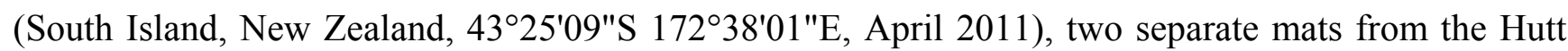

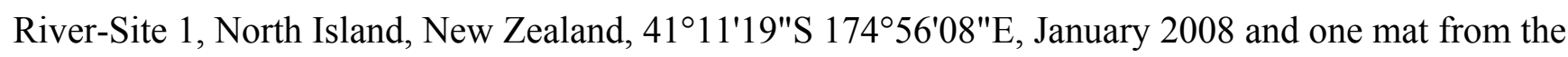

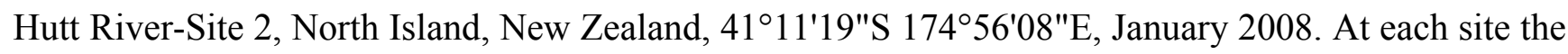
sample was collected by scraping a $1 \mathrm{~cm}^{2}$ area of Phormidium mat from one rock into a sterile Falcon tube $(50 \mathrm{~mL})$. Samples were kept chilled during transport and then frozen $\left(-20{ }^{\circ} \mathrm{C}\right)$ for culturing at a later date.

\subsection{Cyanobacterial Culture Isolation}

Frozen benthic mat samples were thawed and a subsample (ca. $20 \mathrm{mg}$ ) from each sample streaked on to MLA agar $(1 \% w / v,[38])$. Half of the Petri dish containing the streaked material was covered with a black polyvinyl carbonate bag to block light. After 2-3 weeks, single filaments that had migrated across the solid MLA were isolated by micro-pipetting, or by cutting around the agar of a single filament. Isolated trichomes were transferred to 24-well plates containing $500 \mu \mathrm{L}$ of liquid MLA medium per well. Filaments were washed with MLA and incubated under standard conditions $\left(80 \pm 15 \mu \mathrm{mol}\right.$ photons $\mathrm{m}^{-2} . \mathrm{s}^{-1} ; 12: 12 \mathrm{~h}$ light: dark; $\left.18 \pm 1{ }^{\circ} \mathrm{C}\right)$. Successfully isolated strains were maintained in 50-mL plastic bottles (Biolab, New Zealand) under the conditions above. All cultures have been cryopreserved and banked in the Cawthron Institute Culture Collection of Micro-algae (Nelson, New Zealand).

\subsection{Anatoxin- $a$ and Homoanatoxin-a Extraction and Detection}

All cyanobacterial cultures were grown until the early stationary phase. At this phase the cultures had detached from the culture bottle and formed cohesive surface mats which were removed using sterile forceps. Cultures were lyophilized and a sub-sample $(100 \mathrm{mg})$ resuspended in $10 \mathrm{~mL}$ of MilliQ water containing $0.1 \%$ formic acid. Samples were sonicated $(15 \mathrm{~min})$ and centrifuged $(4000 \times g$, $10 \mathrm{~min})$. An aliquot of the supernatant was analysed directly for the anatoxins using LC-MS as described in Heath et al. [2,4]. There are no commercially available standards for dihydroanatoxin-a, homoanatoxin-a, dihydrohomoanatoxin-a and concentrations were calculated using the anatoxin-a calibration curve.

\subsection{Morphological and Molecular Analysis}

Cyanobacterial cultures were identified using an Olympus light microscope (BX51) at 400-2000× magnification with reference to descriptions in Komárek and Anagnostidis [39] and McGregor [40]. Morphological features were recorded including length and width of vegetative cells $(n=30)$, granulation, and apical cell shape.

Molecular analysis of a segment of the 16S rRNA gene sequence was used to characterise the strains and each was screened for a region of anaF, a gene involved in the biosynthesis of anatoxin-a [41]. 
Subsamples $(c a .1 \mathrm{~mL})$ from each strain were centrifuged $(10,000 \times g, 1 \mathrm{~min})$ and the supernatant removed by sterile pipetting. DNA was extracted from the pellets using the PureLinkTM Genomic DNA Kit (Invitrogen, Carlsbad, CA, USA) according to the gram-negative bacteria protocol supplied by the manufacturer. PCR amplification of a region of the anaF and segments from the $16 \mathrm{~S}$ rRNA gene were performed in a three separate $200 \mu \mathrm{L}$ reaction tubes containing $10 \mu \mathrm{L}$ of $\mathrm{i}$-Taq $2 \times$ PCR master mix (Intron, Gyeonggi-do, Korea), $1.2 \mu \mathrm{g}$ non-acetylated bovine serum albumin (Sigma-Aldrich, St. Louis, MO, USA), $0.4 \mu \mathrm{M}$ of each primers (either atxoaf/atxar [13] for the anaF gene, or 27F/809R [42] and 740F/1494R [34,43] for the 16S rRNA gene), and approximately $30 \mathrm{ng}$ of template DNA. Thermal cycling conditions for the anaF PCR were an initial denaturation at $94{ }^{\circ} \mathrm{C}$ for $4 \mathrm{~min}$; followed by 35 cycles of denaturation at $94{ }^{\circ} \mathrm{C}$ for $30 \mathrm{~s}$, annealing at $55{ }^{\circ} \mathrm{C}$ for $30 \mathrm{~s}$ and extension at $72{ }^{\circ} \mathrm{C}$ for $1 \mathrm{~min}$; then a final extension at $72{ }^{\circ} \mathrm{C}$ for $7 \mathrm{~min}$. Conditions for the two $16 \mathrm{~S}$ rRNA PCR's were an initial denaturation at $94{ }^{\circ} \mathrm{C}$ for $2 \mathrm{~min}$; followed by $94{ }^{\circ} \mathrm{C}$ for $1 \mathrm{~min}, 54{ }^{\circ} \mathrm{C}$ for $1 \mathrm{~min}, 72{ }^{\circ} \mathrm{C}$ for $2 \mathrm{~min}$, repeated for 30 cycles; with a final extension at $72{ }^{\circ} \mathrm{C}$ for $7 \mathrm{~min}$. PCR was undertaken on a DNA Engine thermal cycler (Biorad, Hercules, CA, USA). PCR products were visualized by $1 \%$ agarose gel electrophoresis with ethidium bromide staining and UV illumination. Amplicons of the correct size were purified using AxyPrep PCR cleanup kits (Axygen, Union City, CA, USA). Sequencing of selected anaF amplicons and all 16S rRNA amplicons was undertaken using the primers given above and the $3730 \times 1$ DNA Analyser (Applied Biosystems, Carlsbad, CA, USA) using the BigDye Terminator v3.1 Cycle Sequencing Kit (Applied Biosystems, Carlsbad, CA, USA). Sequences generated during this work were compared with sequences from the NCBI GenBank database using Megablast [44] and then deposited in GenBank under accession numbers JX847017-JX847036 and JX088073-JX088093. All sequences were trimmed and aligned using ClustalW in MEGA 4 [45]. A phylogenetic tree was constructed using a neighbor-joining algorithm [46] and Tamura-Nei distance estimates. Pairwise distances were calculated using the Jukes-Cantor method and pairwise deletion was used to account for sequence-length variation and gaps. Bootstrap analyses of 1000 iterations were performed to identify the node support for consensus trees.

\section{Conclusions}

Spatial and temporal variability in anatoxin concentration occurs among benthic Phormidium mats $[2,8,9]$. In this study, 30 strains of Phormidium were isolated from four small sections of benthic mats. Both anatoxin and non-anatoxin-producing genotypes were found to co-occur. There were also 100 fold differences in the amount of anatoxin produced by the toxic strains isolated from a single mat. We speculate that the ratio of anatoxin to non-anatoxin-producing strains, and the varying toxin producing capabilities of each toxic strain within a benthic mat are responsible for the dramatic shifts in anatoxin concentration observed in our previous studies (for example, from 558 to $35 \mathrm{mg} \mathrm{kg}^{-1}$ over 7 days [47]). In-depth studies on environmental samples using quantitative molecular techniques will be required to confirm these hypotheses.

\section{Acknowledgements}

This study was funded by the New Zealand Ministry for Business, Innovation and Employment Cumulative Effects programme (CO1X0803). We thank Michael Boundy for technical assistance with 
the LC-MS analysis, Environment Canterbury for collection of the Waimakariri sample and. Otago Genetic Analysis Services sequencing the PCR products. M. Heath thanks Environment Bay of Plenty, Hawke's Bay Regional Council, Horizons Regional Council, Greater Wellington Regional Council, Environment Canterbury and Environment Southland for financial support. The Institute of Environmental Science and Research Limited, the Biomolecular Interaction Centre, and the Evans Fund are thanked for financial support for F. Smith.

\section{Conflict of Interest}

The authors declare no conflict of interest

\section{References}

1. Gugger, M.; Lenoir, S.; Berger, C.; Ledreux, A.; Druart, J.C.; Humbert, J.F.; Guette, C.; Bernard, C. First report in a river in France of the benthic cyanobacterium Phormidium favosum producing anatoxin-a associated with dog neurotoxicosis. Toxicon 2005, 45, 919-928.

2. Heath, M.; Wood, S.A.; Ryan, K. Polyphasic assessment of fresh-water benthic mat forming cyanobacteria isolated from New Zealand. FEMS Ecol. Microbiol. 2010, 73, 95-109.

3. Wood, S.A.; Kuhajek, J.; de Winton, M.; Phillips, N.R. Species composition and cyanotoxin production in periphyton mats from three lakes of varying trophic status. FEMS Microbiol. Ecol. 2012, 79, 312-326.

4. Wood, S.A.; Selwood, A.I.; Rueckert, A.; Holland, P.T.; Milne, J.R.; Smith, K.F.; Smits, B.; Watts, L.F.; Cary, C.S. First report of homoanatoxin-a and associated dog neurotoxicosis in New Zealand. Toxicon 2007, 50, 292-301.

5. Carmichael, W.W. The toxins of cyanobacteria. Sci. Am. 1994, 270, 78-86.

6. Faassen, E.J.; Harkema, L.; Begeman, L.; Lurling, M. First report of (homo)anatoxin-a and dog neurotoxicosis after ingestion of benthic cyanobacteria in The Netherlands. Toxicon 2012, 60, 378-384.

7. Puschner, B.; Pratt, C.; Tor, E.R. Treatment and diagnosis of a dog with fulminant neurological deterioration due to anatoxin-a intoxication. J. Vet. Emerg. Crit. Care 2010, 20, 518-522.

8. Wood, S.A.; Young, R.G. Review of Benthic Cyanobacteria Monitoring Programme 2012; Cawthron Report No. 2217; Horizon Regional Council: Palmerston North, New Zealand, 2012; p. 30 .

9. Wood, S.A.; Young, R. Benthic Cyanobacteria and Toxin Production in the Manawatu-Wanganui Region; Cawthron Report No. 1959; Horizon Regional Council: Palmerston North, New Zealand, 2011; p. 34.

10. Wood, S.A.; Heath, M.W.; Kuhajek, J.; Ryan, K.G. Fine-scale spatial variability in anatoxin-a and homoanatoxin-a concentrations in benthic cyanobacterial mats: Implication for monitoring and management. J. Appl. Microbiol. 2010, 109, 2011-2018.

11. Kotak, B.G.; Lam, A.K.Y.; Prepas, E.E.; Kenefick, S.L.; Hrudey, S.E. Variability of the hepatotoxin microcystin-LR in hypereutrophic drinking water lakes. J. Phycol. 1995, 31, 248-263. 
12. Vezie, C.; Brient, L.; Sivonen, K.; Bertru, G.; Lefeuvre, J.C.; Salkinoja-Salonen, M. Variation of microcystin content of cyanobacterial blooms and isolated strains in Grand-Lieu lake (France). Microbial. Ecol. 1998, 35, 126-135.

13. Ballot, A.; Fastner, J.; Lentz, M.; Wiedner, C. First report of anatoxin-a-producing cyanobacterium Aphanizomenon issatschenkoi in northeastern Germany. Toxicon 2010, 56, 964-971.

14. Velzeboer, R.M.A.; Baker, P.D.; Rositano, J.; Heresztyn, T.; Codd, G.A.; Raggett, S.L. Geographical patterns of occurrence and composition of saxitoxins in the cyanobacterial genus Anabaena (Nostocales, Cyanophyta) in Australia. Phycologia 2000, 39, 395-407.

15. Vaitomaa, J.; Rantala, A.; Halinen, K.; Rouhiainen, L.; Tallberg, P.; Mokelke, L.; Sivonen, K. Quantitative real-time PCR for determination of microcystin synthetase E copy number for Microcystis and Anabaena in lakes. Appl. Environ. Microbiol. 2003, 69, 7289-7297.

16. Via-Ordorika, L.; Fastner, J.; Kurmayer, R.; Hisbergues, M.; Dittmann, E.; Komárek, J.; Erhard, M.; Chorus, I. Distribution of microcystin-producing and non-microcystin-producing Microcystis sp. in European freshwater bodies: Detection of microcystins and microcystin genes in individual colonies. Syst. Appl. Microbiol. 2004, 27, 582-602.

17. Kurmayer, R.; Christiansen, G.; Fastner, J.; Börner, T. Abundance of active and inactive microcystin genotypes in populations of the toxic cyanobacterium Planktothrix spp. Environ. Microbiol. 2004, 6, 831-841.

18. Saker, M.L.; Fastner, J.; Dittmann, E.; Christiansen, G.; Vasconcelos, V.M. Variation between strains of the cyanobacterium Microcystis aeruginosa isolated from a Portuguese river. J. Appl. Microbiol. 2005, 99, 749-757.

19. Izaguirre, G.; Jungblut, A.D.; Neilan, B.A. Benthic cyanobacteria (Oscillatoriaceae) that produce microcystin-LR, isolated from four reservoirs in southern California. Water Res. 2007, 41, 492-498.

20. Seifert, M.; McGregor, G.; Eaglesham, G.; Wickramasinghe, W.; Shaw, G. First evidence for the production of cylindrospermopsin and deoxy-cylindrospermopsin by the freshwater benthic cyanobacterium, Lyngbya wollei (Farlow ex Gomont) Speziale and Dyck. Harmful Algae 2007, 6, 73-80.

21. Fiore, M.F.; Genuário, D.B.; da Silva, C.S.P.; Shishido, T.K.; Moraes, L.A.B.; Neto, R.C.; Silva-Stenico, M.E. Microcystin production by a freshwater spring cyanobacterium of the genus Fischerella. Toxicon 2009, 53, 754-761.

22. Wood, S.A.; Heath, M.; McGregor, G.; Holland, P.T.; Munday, R.; Ryan, K. Identification of a benthic microcystin producing filamentous cyanobacterium (Oscillatoriales) associated with a dog poisoning in New Zealand. Toxicon 2010, 55, 987-903.

23. Smith, F.; Wood, S.A.; Ginkel, R.V.; Broady, P.; Gaw, S. First report of saxitoxin production by a species of the freshwater benthic cyanobacterium, Scytonema Agardh. Toxicon 2011, 57, 566-573.

24. Cadel-Six, S.; Peyraud-Thomas, C.; Brient, L.; de Marsac, N.T.; Rippka, R.; Méjean, A. Different genotypes of anatoxin-producing cyanobacteria coexist in the Tarn River, France. Appl. Environ. Microbiol. 2007, 73, 7605-7614. 
25. Rinta-Kanto, J.M.; Ouellette, A.J.; Boyer, G.L.; Twiss, M.R.; Bridgeman, T.B.; Wilhelm, S.W. Quantification of toxic Microcystis spp. during the 2003 and 2004 blooms in western Lake Erie using quantitative real-time PCR. Environ. Sci. Technol. 2005, 39, 4198-4205.

26. Rantala-Ylinen, A.; Känä, S.; Wang, H.; Rouhiainen, L.; Wahlsten, M.; Rizzi, E.; Berg, K.; Gugger, M.; Sivonen, K. Anatoxin-a synthetase gene cluster of the cyanobacterium Anabaena sp. strain 37 and molecular methods to detect potential producers. Appl. Environ. Microbiol. 2011, 77, 7271-7278.

27. Wood, S.A.; Rhodes, L.; Adams, S.; Adamson, J.; Smith, K.; Smith, J.; Tervit, R.; Cary, S.C. Maintenance of cyanotoxin production by cryopreserved New Zealand culture collection cyanobacteria. N.Z. J. Mar. Freshwat. Res. 2008, 42, 277-283.

28. Devlin, J.P.; Edwards, O.E.; Gorham, P.R.; Hunter, M.R.; Pike, R.K.; Stavric, B. Anatoxin-a, a toxic alkaloid from Anabaena flos-aquae NCR-44. Can. J. Chem. 1977, 55, 1367-1371.

29. Skulberg, O.M.; Carmichael, W.W.; Andersen, R.A.; Matsunaga, S.; Moore, R.E.; Skulberg, R. Investigations of a neurotoxic Oscillatorialean strain (Cyanophyceae) and its toxin isolation and characterization of homoanatoxin-a. Environ. Tox. Chem. 1992, 11, 321-329.

30. Bates, H.A.; Rapoport, H. Synthesis of anatoxin-a via intramolecular cyclization of iminium salts. J. Am. Chem. Soc. 1979, 101, 1259-1265.

31. Comte, K.; Sabacka, M.; Carre-Mlouka, A.; Elster, J.; Komarek, J. Relationships between the Arctic and the Antarctic cyanobacteria; three Phormidium like strains evaluated by a polyphasic approach. FEMS Microbiol. Ecol. 2007, 59, 366-376.

32. Palinska, K.A.; Marquardt, J. Genotypic and phenotypic analysis of strains assigned to the widespread cyanobacterial morphospecies Phormidium autumnale (Oscillatoriales). Arch. Microbiol. 2008, 189, 325-335.

33. Lyra, C.; Suomalainen, S.; Gugger, M.; Vezie, C.; Sundman, P.; Paulin, L.; Sivonen, K. Molecular characterization of planktic cyanobacteria of Anabaena, Aphanizomenon, Microcystis and Planktothrix genera. Int. J. Syst. Evol. Microbiol. 2001, 51, 513-526.

34. Neilan, B.A.; Jacobs, D.; del Dot, T.; Blackall, L.L.; Hawkins, P.R.; Cox, P.T.; Goodman, A.E. rRNA sequences and evolutionary relationships among toxic and nontoxic cyanobacteria of the genus Microcystis. Int. J. Syst. Bacteriol. 1997, 47, 693-697.

35. Baker, J.; Entsch, B.; Neilan, B.; McKay, D. Monitoring changing toxigenicity of a cyanobacterial bloom by molecular methods. Appl. Environ. Microbiol. 2002, 68, 6070-6076.

36. Ouellette, A.J.; Wilhelm, S.W. Toxic cyanobacteria: The evolving molecular toolbox. Front. Ecol. Environ. 2003, 1, 359-366.

37. Komárek, J. Problems in Cyanobacterial Taxonomy: Implications for Most Common Toxin Producing Species. In Workshop the Blooms of Toxic Algae in Fresh Waters: Health Emergency and Control Measures; Melchiorre, S., Viaggiu, E., Bruno, M., Eds.; National Institute of Health: Rome, Italy, 2000; pp. 6-43.

38. Bolch, C.J.S.; Blackburn, S.I. Isolation and purification of Australian isolates of the toxic cyanobacterium Microcystis aeruginosa Kütz. J. Appl. Phycol. 1996, 8, 5-13.

39. Komárek, J.; Anagnostidis, K. Cyanoprokaryota: 2. Teil: Oscillatoriales; Elsevier GmbH: München, Germany, 2005; Volume 19/2, pp. 1-759. 
40. McGregor, G.B. Freshwater Cyanoprokaryota of North-Eastern Australia 1: Oscillatoriales; Australian Biological Resources Study: Canberra, Australia, 2007; p. 123.

41. Méjean, A.; Mann, S.; Maldiney, T.; Vassiliadis, G.; Lequin, O.; Ploux, O. Evidence that biosynthesis of the neurotoxic alkaloids anatoxin-a and homoanatoxin-a in the cyanobacterium Oscillatoria PCC 6506 occurs on a modular polyketide synthase initiated by 1-proline. J. Am. Chem. Soc. 2009, 131, 7512-7513.

42. Jungblut, A.; Neilan, B.A. Molecular identification and evolution of the cyclic peptide hepatotoxins, microcystin and nodularin, synthetase genes in three orders of cyanobacteria. Arch. Microbiol. 2006, 185, 107-114.

43. Frazão, B.; Martins, R.; Vasconcelos, V. Are known cyanotoxins involved in the toxicity of picoplanktonic and filamentous North Atlantic marine cyanobacteria? Mar. Drugs 2010, 8, 1908-1919.

44. Benson, D.A.; Karsch-Mizrachi, I.; Lipman, D.J.; Ostell, J.; Wheeler, D.L. GenBank. Nucleic Acids Res. 2008, 36, D25-D30.

45. Tamura, K.; Dudley, J.; Nei, M.; Kumar, S. MEGA4: Molecular Evolutionary Genetics Analysis (MEGA) software version 4.0. Mol. Biol. Evol. 2007, 24, 1596-1599.

46. Saitou, N.; Nei, M. The neighbor-joining method: A new method for reconstructing phylogenetic trees. Mol. Biol. Evol. 1987, 4, 406-425.

47. Heath, M.; Wood, S.A.; Ryan, K. Spatial and temporal variability in Phormidium sp. abundance and toxin production in the Hutt River, New Zealand. Aquat. Environ. Microbiol. 2011, 64, $69-79$.

(C) 2012 by the authors; licensee MDPI, Basel, Switzerland. This article is an open access article distributed under the terms and conditions of the Creative Commons Attribution license (http://creativecommons.org/licenses/by/3.0/). 